variation in temperature in different analyses. In some we get conditions favorable for a loss of alkali, in some for a loss of $\mathrm{Al}_{2} \mathrm{O}_{3}$ and sometimes for both. We have, with great care in heating, obtained only slightly low results where both $\mathrm{Al}_{2} \mathrm{O}_{3}$ and $\mathrm{Na}_{2} \mathrm{O}$ were very high as in cryolite. The loss therefore probably can be prevented.

Boric oxide tends to alleviate the difficulty caused by alumina and it does not in any way interfere with later determinations. Borosilicates with up to 5 per cent $\mathrm{Al}_{2} \mathrm{O}_{3}$ give fairly good results. One showed 4.82 per cent $\mathrm{Al}_{2} \mathrm{O}_{3}$ and $0.10 \mathrm{IO}$ g. alkali chlorides by regular methods and 4.93 per cent $\mathrm{Al}_{2} \mathrm{O}_{3}$ and $0.1027 \mathrm{~g}$. alkali chlorides by the oxalate method. The results on glass $\mathrm{G}$ mentioned in the table are not very good, however. With glasses not containing $\mathrm{B}_{2} \mathrm{O}_{3}$ the addition of boric acid before evaporation with $\mathrm{HF}$ and $\mathrm{H}_{2} \mathrm{C}_{2} \mathrm{O}_{4}$ decreased the fluorine content of the soluble oxalates and also gave higher results for $\mathrm{Al}_{2} \mathrm{O}_{3}$ and alkali without showing any $\mathrm{B}_{2} \mathrm{O}_{3}$ present with the alkali.

From the results so far we do not feel confidence in the method for such glasses as show undecomposed silico-fluorides, for while accurate determinations may be obtained with special precautions the method has no advantages under such conditions. For glasses which do not contain much $\mathrm{Al}_{2} \mathrm{O}_{3}$ the method seems well adapted, especially for the analysis of a series of glasses of very nearly the same composition. We have also found it convenient for the rapid determination of $\mathrm{As}_{2} \mathrm{O}_{3}$ or $\mathrm{Sb}_{2} \mathrm{O}_{3}$ in glass.

\section{DETERMINATION OF BORIC ACID}

In the analysis of borosilicate glasses we have found that for the determination of boric oxide the method described by $W_{h e r r y}{ }^{1}$ is very useful:

"Fuse the sample with about $3 \mathrm{~g}$. of $\mathrm{Na}_{2} \mathrm{CO}_{3}$ for 15 minutes. Take up with 20 to $30 \mathrm{cc}$. of dilute $\mathrm{HCl}$ adding a few drops of $\mathrm{HNO}_{3}$ to oxidize ferrous iron. Place in a $250 \mathrm{cc}$. round-bottomed flask, heat nearly to boiling, and add dry precipitated $\mathrm{CaCO}_{3}$ in moderate excess. Connect with a return condenser and boil vigorously for about ro minutes. Filter out the precipitate through a small Büchner funnel, washing several times with hot water, but keeping the total volume of liquid below roo cc. Return the filtrate to the flask, add a pinch of $\mathrm{CaCO}_{3}$ and again heat to boiling; then connect with a filter pump, through a splash trap, and continue suction until the boiling has nearly ceased. Cool to the ordinary temperature, filter if the precipitate has a red color from iron, add four or five drops of phenolphthalein and run in slowly $\mathrm{N} / \mathrm{I}$ o $\mathrm{NaOH}$ solution until the liquid is strongly pink in color. Introduce about $\mathrm{I} \mathrm{g}$. of mannite and shake, whereupon the pink color will disappear: Add $\mathrm{NaOH}$ to end reaction, then another gram of mannite and if necessary more alkali until a permanent pink color is obtained."

The method was first tried by fusing $0.5 \mathrm{~g}$. sand and $0.2 \mathrm{~g}$. boric acid with $3 \mathrm{~g}$. soda. The melted mass was taken up with water and $7 \mathrm{cc}$. conc. $\mathrm{HCl}$ added after transfer to a $250 \mathrm{cc}$. flask. The method was then followed as described above except titration was made with $\mathrm{Ba}(\mathrm{OH})_{2}$. The $\mathrm{B}_{2} \mathrm{O}_{3}$ content came from 2 to 10 per cent low, due to retention of $\mathrm{B}_{2} \mathrm{O}_{3}$ by the precipitate' from $\mathrm{CaCO}_{3}$. By using suction in filtering and washing this precipitate practically roo per cent of the $\mathrm{B}_{2} \mathrm{O}_{3}$ introduced was recovered. For $0.25 \mathrm{~g}$. $\mathrm{B}_{2} \mathrm{O}_{3}=\mathrm{I} 2.40 \mathrm{Ba}(\mathrm{OH})_{2}$ we used $\mathrm{I} 2.35$ and $\mathrm{I} 2.40 \mathrm{cc}$.

1 J. Am. Chem. Soc., 30 (1908), 1687.
As iron and alumina are rarely present in large amounts in glass and as the time of the soda fusion with glass can be cut to a few minutes the method seemed quite readily adaptable.

The first glass tried was a soda alumina borosilicate which, from analysis, showed a possible $\mathrm{B}_{2} \mathrm{O}_{3}$ content of 10.40 per cent by difference. Three determinations by Wherry's method showed I0.72, I0.57, 10.67 per cent $\mathrm{B}_{2} \mathrm{O}_{3}$ or an average of 10.64 per cent. A soda borosilicate containing a small amount of $\mathrm{BaO}$ and $\mathrm{Sb}_{2} \mathrm{O}_{3}$ showed 25.57 per cent $\mathrm{B}_{2} \mathrm{O}_{3}$ by Wherry's method and 25.75 per cent by difference. Other glasses of same type showed:

Per cent $\mathrm{B}_{2} \mathrm{O}_{3}$ by titration
25.10
12.71
17.57
14.90

Per cent $\mathrm{B}_{2} \mathrm{O}_{3}$ by difference 25.12
12.15
17.51
15.01

With a zinc borosilicate very unsatisfactory results were obtained, the $\mathrm{B}_{2} \mathrm{O}_{3}$ content by titration running from 4 to 9 per cent when only 2 per cent was present. Several mixtures of $\mathrm{ZnO}$ and sand with a known amount of $\mathrm{B}_{2} \mathrm{O}_{3}$ were run through by Wherry's method and results for $\mathrm{B}_{2} \mathrm{O}_{3}$ were always high even after very long boiling. Solutions of $\mathrm{ZnCl}_{2}$ and borax were boiled with $\mathrm{CaCO}_{3}$ for varying lengths of time and using slight excess and large excess of $\mathrm{CaCO}_{3}$ and zinc was always found in the filtrate from the $\mathrm{CaCO}_{3}$ precipitate. $\mathrm{CaO}$ was substituted for $\mathrm{CaCO}_{3}$ but with no better success. $\mathrm{Na}_{2} \mathrm{CO}_{3}$ completely removed the zinc from solution and by a double precipitation, using first $\mathrm{Na}_{2} \mathrm{CO}_{3}$ and then $\mathrm{CaCO}_{3}$, we obtained 0.0360 , $0.036 \mathrm{I}$ and $0.0365 \mathrm{~g} . \mathrm{B}_{2} \mathrm{O}_{3}$ when the theoretical amount was $0.0365 \mathrm{~g}$. $\mathrm{PbO}$ was found to cause the same trouble as $\mathrm{ZnO}$ and the same modification of the method gave satisfactory results. We have been able to use the modified method on a large number of glasses with satisfactory results.

The modified method then is as follows: Fuse $0.5 \mathrm{~g}$. of glass with $3 \mathrm{~g}$. $\mathrm{Na}_{2} \mathrm{CO}_{3}$ for one or two minutes after mass is liquid." Take up with 20 to $30 \mathrm{cc}$. of hot water and when the melt is entirely decomposed filter out any insoluble oxides. After washing, transfer filtrate and washings to a $250 \mathrm{cc}$. round-bottomed flask, add about $7 \mathrm{cc}$. concentrated $\mathrm{HCl}$, heat nearly to boiling and add dry precipitated $\mathrm{CaCO}_{3}$ in moderate excess. From here on the method is as given by Wherry except that we used $\mathrm{Ba}(\mathrm{OH})_{2}$ instead of $\mathrm{NaOH}$. It is also advisable to use suction for filtering the $\mathrm{CaCO}$ precipitate.

Corning Glass Works, Corning, New York

\section{THE COMPOSITION OF MILK AS SHOWN BY ANALYSES 3 OF SAMPLES OF KNOWN PURITY MADE BY THE MASSACHUSETTS STATE BOARD OF HEALTH}

By Hermann C. Lythgoe

Received June 19, 1914

Milk, without doubt, is the most extensively adulterated of any article of human food and, by reason of its variable composition, the detection of this adulteration is difficult and in some cases impossible. For these reasons most legislative bodies, in addition to prohibiting the sale of adulterated milk, prohibit the sale of milk, the composition of which falls below 
specified standards and in some places, as in the State of Massachusetts, the penalty for the sale of milk which is adulterated is more severe than that for the sale of milk below the legal standard. The milk analyst in such localities must familiarize himself with the composition of natural milk in order to detect and distinguish between milk which is adulterated and that which is simply below the legal standard. The usual methods of adulterating milk are the addition of water, the removal of cream or performance of both acts, the ease of which as well as the resulting profit has considerable to do with the extent of milk adulteration. As water is a natural component of milk, the detection of added water, as well as the removal of cream, can be accomplished only by showing abnormal chemical or physical constants which are consistent with the nature of the adulteration. Either or both of these forms of adulteration may be practised to a limited extent and be impossible of detection.

During the past six years, from 600 to 700 samples of known purity milk have been examined in the laboratory of food and drug inspection of the Massachusetts State Board of Health of which nearly 500 samples have beer subject to a fairly complete analysis, 434 of which came from individual cows and the balance from herds. These samples were obtained from Jerseys, Guernsey, Ayrshire, Dutch Belt, and Holstein cows, as well as from cross-bred or socalled grade cows. The methods of analysis used were as follows:

TOTAL solids, as used by the Massachusetts State Board of Health for thirty years: Evaporate $5 \mathrm{~g}$. of milk in a flat-bottomed platinum dish over a boiling water bath for 2 hrs. and weigh the residue.

ASH: Burn in a muffle the residue obtained as above, and weigh the ash.

FAT: By the Babcock method.

PROTEINS: From the percentage of nitrogen by the Gunnitig method using the factor 6.38 .

LACTOSE: By the polariscopic method of the A. O. A. C., mercuric nitrate being used as a clarifier. If lead is used as a clarifier, the results are low, owing to the precipitation of lactose.

MIIK SERUM-(I) COPPER METHOD: ${ }^{1}$ Add four volumes of milk to one volume of copper sulfate solution $\left(72.5 \mathrm{~g}\right.$. per liter adjusted to read 36.0 at $20^{\circ} \mathrm{C}$. on the scale of the Zeiss Immersion Refractometer or to a specific gravity of $\mathrm{I} .0443$ at $20 / 4^{\circ} \mathrm{C}$.), shake well and filter.

(2) ACETIC ACID METHOD: ${ }^{2}$ To Ioo cc. of milk add 2 cc. of 25 per cent acetic acid, heat for 20 minutes in a water bath at $70^{\circ}, \mathrm{cool}$ ro minutes in ice water and filter.

(3) MODIFICATION OF PFYL AND TURNAU ${ }^{3}$ called tetra serum $I$, giving the same serum which has been substituted in some instances for the acetic acid method. Shake $50 \mathrm{cc}$. of milk with $5 \mathrm{cc}$. of carbon tetrachloride in a shaking. machine for 5 minutes, add I cc. of 20 per cent acetic acid, shake again for 5 minutes, centrifuge and pour off the clear serum.

\footnotetext{
1 Lythgoe, Mass. State Board of Health Report, 1908, p. 594

2 Leach and Iy.thgoe, $J$. Am. Chem. Soc., 1904, p. 1195.

3 Arb. Kais. Ges.. 40, 247.
}

(4) SOUR SERUM:1 Allow the milk to sour spontaneously and filter.

(5) ASH OF SOUR SERUM:2 Measure $25 \mathrm{cc}$. of the sour milk serum into a platinum dish, evaporate to dryness and burn in a muffle at a temperature not above $550^{\circ} \mathrm{C}$. Weigh the residual ash.

The summary of the analyses of the samples arranged according to breeds in the order of the average total solids is given in Table I. Determinations of solids, fat, proteins, ash, and sugar were made upon all the samples, and the serum was prepared from nearly all the samples by one or more methods.

The variation in the composition of milk is due primarily to the breed of the cow but is more or less influenced by the period of lactation and the season of the year. It is very generally known that cows of the Jersey and Guernsey type give better milk than those of the Holstein variety, that cows far along in lactation give richer milk than just after calving and that milk obtained in the summer is inferior in quality to that obtained in the winter although popular opinion is opposed to this latter statement. The solids naturally show the highest numerical variation, from I7.17 to I0.20 per cent in the milk from individual cows and from I 4.57 to II.56 per cent in herd milk. The constituents having the most influence upon this variation are first the fat and to a less extent the proteins, the former varying from 7.7 to 2.45 per cent in milk from individual cows and from 5.40 to 3.35 per cent in herd milk and the latter from $5.0 \mathrm{I}$ to 2 per cent in milk from individual cows and from 4.02 to 2.66 per cent in herd milk. The numerical variation of the ash is very slight and that of the sugar is the least of the major constituents, the latter being from 5.80 to $3.9 \mathrm{I}$ per cent in milk from individual cows and from 5.25 to 4.35 per cent in herd milk.

The percentage variation is more marked than the numerical variation, being the greatest in the fat and least in the sugar. Owing to the presence of a few samples of abnormally high concentration, the percentage variations above the average are greater than those below the average.

\section{Solids vary from 32 per cent above to 21 per cent below the average Fat varies from 83 per cent above to 42 per cent below the average Proteins vary from 53 per cent above to 39 per cent below the average Sugar varies from 32 per cent above to 18 per cent below the average \\ Minimum solids were 40 per cent below the maximum solids \\ Minimum fat was 68 per cent below the maximum fat \\ Minimum proteins were 50 per cent below the maximum proteins \\ Minimum sugar was 32 per cent below the maximum sugar}

Excluding some of the abnormally high figures these variations would be reduced. It is unusual to find the solids above $I 7$ or below I0.5 per cent, the fat above 7 or below 2.5 per cent, the proteins above 4.5 or below 2.4 per cent, the solids-not-fat above Io or below 7.8 per cent, and the sugar above 5.5 or below 4.3 per cent. Using these limits, which eliminates 26 samples, the variations from the average are much less than those calculated from all the samples.

Solids would vary from 31 per cent above to 19 per cent below the average Fat would vary from 66 per cent above to 41 per cent below the average Proteins would vary from 38 per cent above to 27 per cent below the average Sugar would vary from 15 per cent above to 10 per cent below the average Minimum solids would be 38 per cent below the maximum solids Minimum fat would be 64 per cent below the maximum fat

Minimum proteins would be 47 per cent below the maximum proteins Minimum sugar would be 22 per cent below the maximum sugar

1 Matthes and Muller, Z. offenil. Chem., 9 (1903), 173.

${ }^{2}$ Burr and Berberich, Chem. Zig., 32, 617 


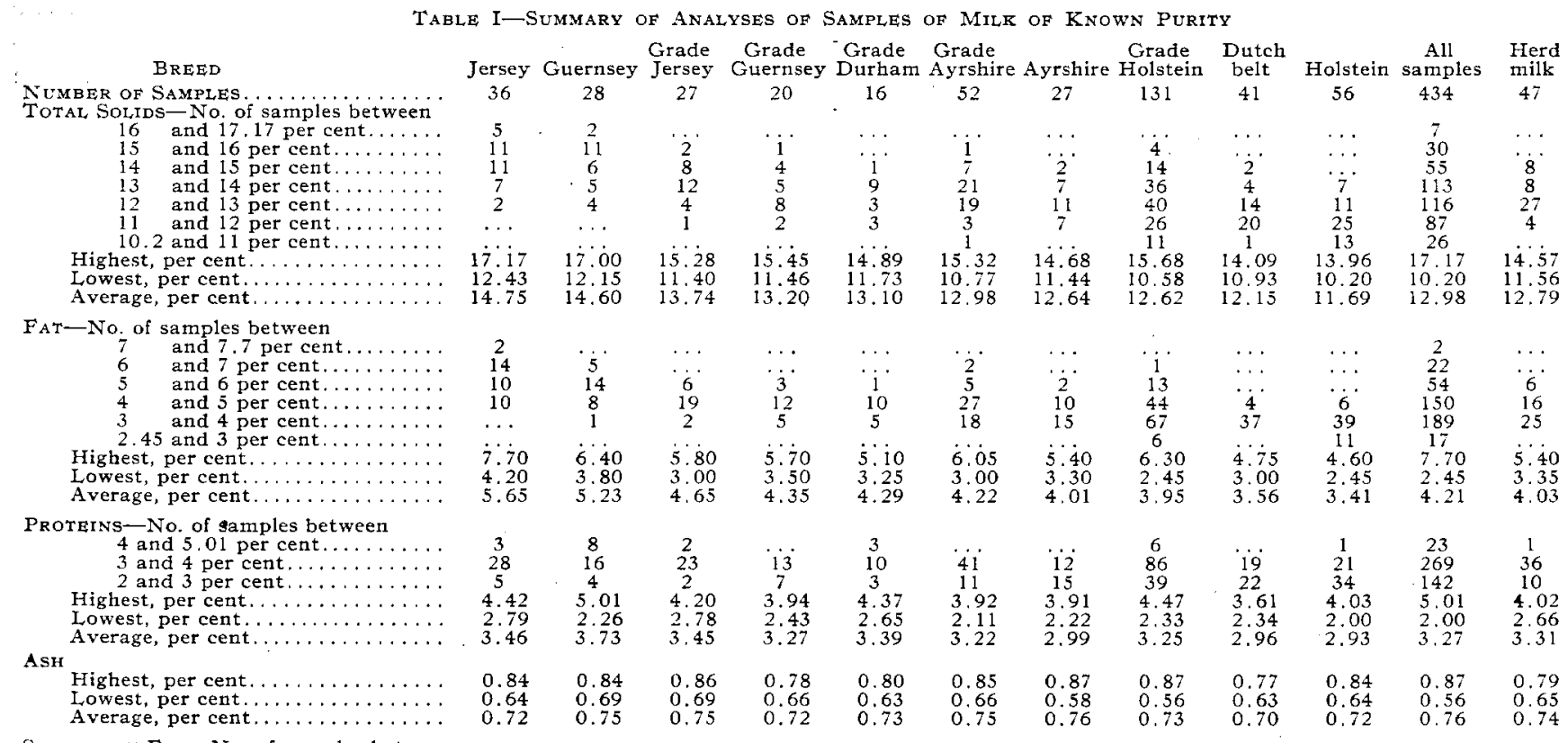

SolidS-NOT-FAT-No. of samples between

$10 \quad$ and 10.65 per cent.........
9 and 10 per cent...........
8 and 9 per cent..........

Highest, per cent....................

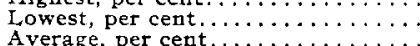

Mili Sugar - No. of samples between

5 and 5.80 per cent.........

Highest, per cent.

Lowest, per cent

Average, per cent

Protein-Fat Ratio

Howest.

Average .....................

Fat in Total Solids

Highest, per cent ................
Lowest, per cent................

A verage, per cent...................

REFRACTION OF COPPER SERUM AT $20^{\circ} \mathrm{C}$.

No. of samples between

40 and $40.4 \ldots \ldots \ldots \ldots \ldots$

39 and 40

37 and 38

TOTAL NO OF SAMPLE

Highest, scale reading.

Lowest, scale reading

Avera scale reading ............. 37.1

REFRACTION OF ACETIC SERUM AT $20^{\circ} \mathrm{C}$.

So. of samples between

45 and 47.5 .

44 and 45.

43 and 44

41 and 42

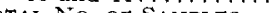

Total No. or Samples..............

Lighest, scale reading.

Average, scale reading............ 42.4

REFRACTION OF SOUR MILK SERUM AT $20^{\circ} \mathrm{C}$.

No. of samples between

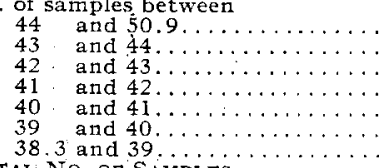

38.3 and 39.

Total No. OF SAMPLES...............

Lowest, scale reading.

Average, scale reading

Ash OF SOUR MILK SERUM

No. of samples between
0.9 and $0.932 \mathrm{~g}$. per $100 \mathrm{cc}$
0.8 and 0.8 and $0.9 \mathrm{~g}$. per $100 \mathrm{cc}$.

0.730 and $0.8 \mathrm{~g}$. per $100 \mathrm{cc}$
TOTAL No. OF SAMPLES

TOTAL NO. OF SAMPLES.
Highest, g. per $100 \mathrm{cc}$.

Lowest, g. per $100 \mathrm{cc}$.

Average, g. per 100 ec.

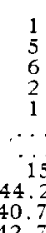

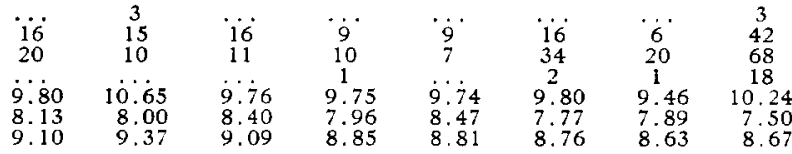

$\begin{array}{ll}20 & 7 \\ 16 & 21 \\ \cdots & 5\end{array}$

5. 80

7.9

5.2
4.46

9

10

\section{4}

17
35
5

5.46
4.35
4.87

5.34
4.50

5.29
4.36

35
5.75

16
11
5.30
4.05

40
90
1
5.58
3.91

3
29
3
9.43

9
29
3
.43
.63
8.59

7.
39
12
9.61
7.55

$\begin{array}{cc}6 & \\ 143 & 17 \\ 248 & 29 \\ 37 & 1 \\ 106 & 9\end{array}$

0.80
0.46

$\begin{array}{ll}0.82 & 0.86 \\ 0.55 & 0.58\end{array}$

0.90
0.60

0.60
0.75

0.91
0.62
0.79

4.20
4.85

4.88

3.91
4.65

$\frac{14}{27}$

14
27
.35
.90

9
47
5.20
4.20

7.50
8.77

17
29
1
9.48
7.63
8.76

38.6

38

0.98
0.56

0.92
0.59
0.75

0.99
0.55
0.82

\section{4}

36.3
27.2
31.8

40.
25
31

40.0
25.0
31.3

31.
26.

\subsection{7}

0.97
0.71
0.83

$\begin{array}{lll}0.99 & 0.99 & 0.95\end{array}$

$\begin{array}{lll}0.99 & 0.99 & 0.95 \\ 0.62 & 0.46 & 0.66 \\ 0.86 & 0.78 & 0.82\end{array}$

$\begin{array}{lll}3.9 & 30.1 & 30.6 \\ 33.9 & 33 .\end{array}$

$\begin{array}{cccc}3 & i & 3 & i \\ 22 & 17 & 8 & 8 \\ 3 & 9 & 11 & 7 \\ 31 & 27 & 21 & \because 6 \\ 39.5 & 39.0 & 39.3 & 39.0 \\ 37.1 & 37.0 & 37.2 & 36.6 \\ 38.1 & 38.2 & 38.0 & 38.0\end{array}$

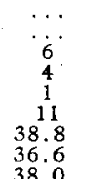

7
17
20
5
49
39.7
36.0
37.9
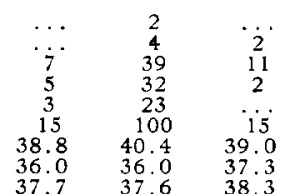

33.

25.4.

77.4
25.0
32.5

37.1
28.2
$31 \cdot 6$
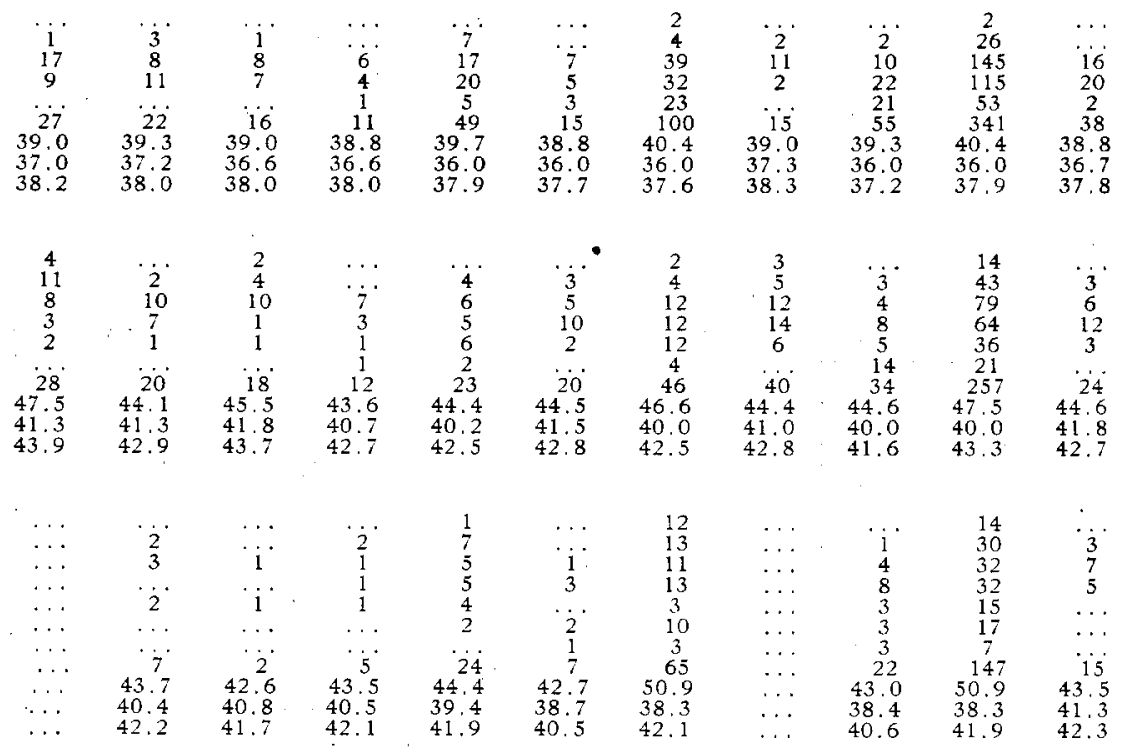

3
3
6
12
3
24
44.6
41.8
42.7
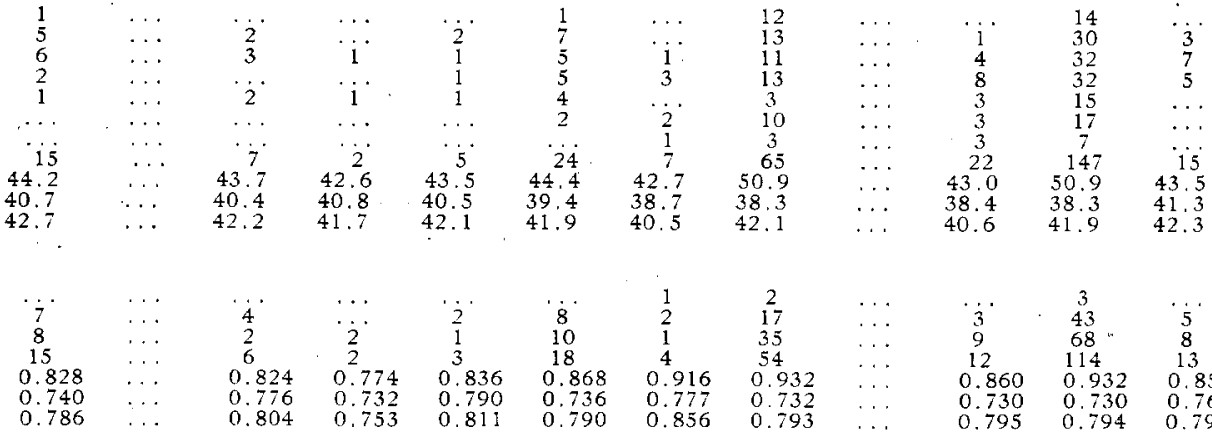
The variations calculated from the analyses of the herd milk are, of course, much less than those obtained from the milk of individual cows. Experience has shown it to be improbable that cows giving abnormal milk will be present even in small herds of six or eight in sufficient numbers to render the herd milk abnormal. Of the herd milk,

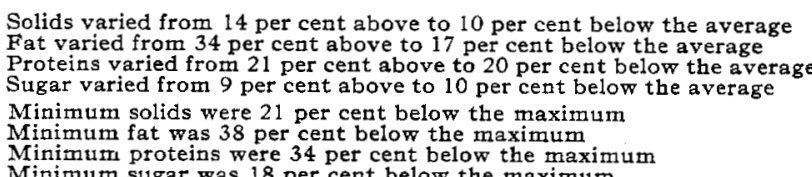

The solids-not-fat (consisting of the proteins, lactose and ash) are much less variable than the solids or the fat and formerly was the only figure used in detecting added water, yet the variation here is considerable. A less variable figure, the soluble solids (consisting of the albumin, ash, and sugar varying between 5.95 and 6.45 per cent in herd milk and between 5.80 and 6.60 per cent in milk from individual cows), has been suggested by Cornalba ${ }^{1}$ as a means of detecting added water, and this is substantially what is obtained when preparing the milk serum.

It has been known that the composition of milk is influenced by the season and by the time since calving. In order to show if these variations existed in the samples examined, the Grade Holstein, Grade Durham, Ayrshire and Grade Ayrshire milk were selected, thus excluding the exceptionally high Jersey and Guernsey and the exceptionally low Holstein and Dutch Belt figures. These 224 analyses were first arranged by months and because of the small number of samples obtained in some months, the averages were not representative and the arrangement was therefore made by seasons. Of these samples, the period of lactation was known in 194 cases and seasonal averages were made of these, together with averages of the same analyses arranged according to the period of lactation. These figures, together with the variation according to season of the herd milk, are shown in Table II. by no means as marked as those observed between the different breeds. The period of lactation appears to have no influence upon the variation by season for in the series of 194 samples arranged by seasons, the average period of lactation was practically the same in each season. All the results are affected by the seasonal variation and all but the sugar and serum figures are affected by the period of lactation. The protein-fat ratio and the percentage of fat in the solids of these samples were not materially affected either by the season or by the period of lactation.

\section{RELATION BETWEEN THE MILK SOLIDS AND ITS CON STITUENTS}

RELATION BEIWEEN THE SOLIDS AND THE FAT-The percentage of fat in the solids decreases with the solids; in the Jersey milk, it averages 38 and in the Holstein milk 27 per cent. The highest figure was 47.4 obtained from a sample of Jersey milk and the lowest 25.0 per cent, from a sample of Holstein milk.

RELATION BETWEEN THE SOLIDS AND PROTEINS--The amount of proteins in the solids is fairly constant at about 25 per cent. Olson ${ }^{1}$ has given for the approximate calculation of the protein from the solids the formula $\mathrm{P}=\mathrm{T} \mathrm{S}-\frac{\mathrm{TS}}{\mathrm{I} .34}$ where $\mathrm{P}$ equals proteins and $T$ S equals total solids.

RELATION BETWEEN THE SOLIDS AND THE ASH-AS the ash is nearly constant, the percentage of ash in the solids increases as the solids diminish, being 4.9 in Jersey milk and 6.7 per cent in Holstein milk.

RELATION BETWEEN THE TOTAL SOLIDS AND SUGARLike the ash the sugar is nearly constant and the percentage of sugar in the solids increases as the solids decrease. In Jersey milk the average figure is 30 and in Holstein milk 40 per cent.

\section{RELATION BETWEEN THE DIFFERENT MILK CONSTITUENTS}

PROTEIN-FAT RATIO-This has been extremely studied

Table II-Known Purity Milk samples arranged according to Shasons and Period of Lactation

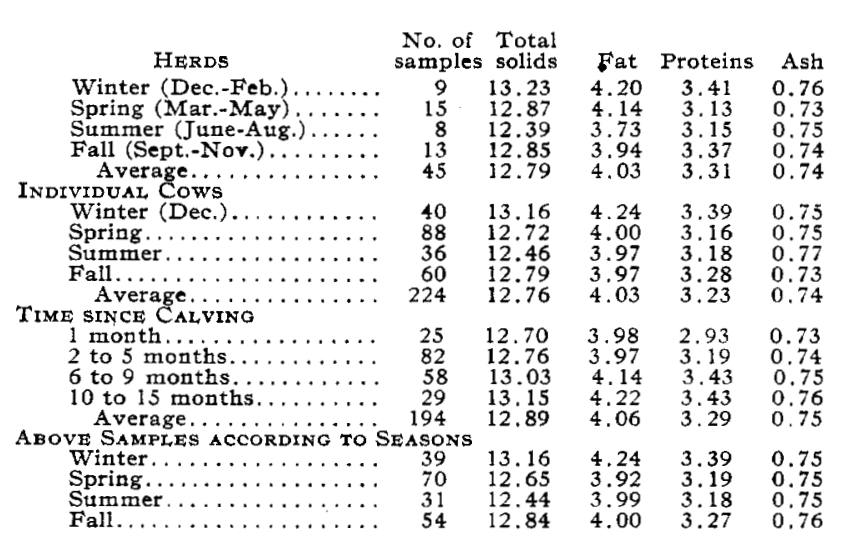

A perusal of this table concerning the seasonal variation shows that milk obtained in the winter is the best, that obtained in the summer is the worst, while milk obtained in the spring and fall is a mean of the summer and winter samples. These differences, however, are 1 Ann. Fals., 2, 529.

\begin{tabular}{|c|c|c|c|c|}
\hline \multirow{2}{*}{$\begin{array}{c}\text { Solids } \\
\text { not } \\
\text { fat }\end{array}$} & \multirow[b]{2}{*}{ Iactose } & \multicolumn{3}{|c|}{ Refraction of serum } \\
\hline & & Copper & Acetic & Sour \\
\hline $\begin{array}{l}9.03 \\
8.74 \\
8.66 \\
8.91 \\
8.76\end{array}$ & $\begin{array}{l}4.88 \\
4.92 \\
4.71 \\
4.80 \\
4.83\end{array}$ & $\begin{array}{l}37.9 \\
38.3 \\
37.5 \\
37.7 \\
37.8\end{array}$ & $\begin{array}{l}44.3 \\
43.3 \\
42.3 \\
42.8 \\
42.7\end{array}$ & $\begin{array}{l}42.2 \\
42.5 \\
42.2 \\
41.7 \\
42.3\end{array}$ \\
\hline $\begin{array}{l}8.92 \\
8.72 \\
8.59 \\
8.82 \\
8.73\end{array}$ & $\begin{array}{l}4.80 \\
4.78 \\
4.55 \\
4.84 \\
4.77\end{array}$ & $\begin{array}{l}38.2 \\
37.7 \\
37.3 \\
37.9 \\
37.7\end{array}$ & $\begin{array}{l}43.7 \\
42.5 \\
41.9 \\
42.4 \\
42.5\end{array}$ & $\begin{array}{l}43.1 \\
42.0 \\
39.8 \\
40.4 \\
41.3\end{array}$ \\
\hline $\begin{array}{l}8.72 \\
8.79 \\
8.89 \\
8.93 \\
8.83\end{array}$ & $\begin{array}{l}4.90 \\
4.86 \\
4.71 \\
4.75 \\
4.81\end{array}$ & $\begin{array}{l}38.1 \\
37.7 \\
37.7 \\
37.7 \\
37.7\end{array}$ & $\begin{array}{l}42.1 \\
42.6 \\
42.3 \\
43.4 \\
42.6\end{array}$ & $\begin{array}{l}42.6 \\
41.8 \\
42.0 \\
42.2 \\
42.1\end{array}$ \\
\hline $\begin{array}{l}8.92 \\
8.73 \\
8.45 \\
8.84\end{array}$ & $\begin{array}{l}4.80 \\
4.78 \\
4.55 \\
4.87\end{array}$ & $\begin{array}{l}38.2 \\
37.7 \\
37.3 \\
37.9\end{array}$ & $\begin{array}{l}43.7 \\
42.5 \\
41.9 \\
42.4\end{array}$ & $\begin{array}{l}43.1 \\
42.0 \\
39.8 \\
40.4\end{array}$ \\
\hline
\end{tabular}

$\begin{array}{ccc}\begin{array}{c}\text { Ash } \\ \text { of sour } \\ \text { serum }\end{array} & \begin{array}{c}\text { Protein- } \\ \text { fat } \\ \text { ratio }\end{array} & \begin{array}{c}\text { Per } \\ \text { cent } \\ \text { fat id } \\ \text { solids }\end{array} \\ 0.779 & 0.81 & 31.7 \\ 0.789 & 0.76 & 32.2 \\ 0.853 & 0.84 & 30.1 \\ 0.775 & 0.86 & 30.7 \\ 0.792 & 0.82 & 31.6 \\ 0.778 & 0.80 & 32.2 \\ 0.811 & 0.79 & 31.4 \\ 0.803 & 0.80 & 31.8 \\ 0.801 & 0.83 & 31.1 \\ 0.809 & 0.80 & 31.6 \\ 0.785 & 0.74 & 31.3 \\ 0.779 & 0.78 & 31.1 \\ 0.817 & 0.83 & 31.7 \\ 0.788 & 0.81 & 32.1 \\ 0.793 & 0.81 & 31.6 \\ 0.778 & 0.80 & 32.2 \\ 0.811 & 0.82 & 31.0 \\ 0.803 & 0.80 & 32.0 \\ 0.801 & 0.82 & 31.2\end{array}$

Average period of
lactation

by $\operatorname{Van}$ Slyke $^{2}$ and his average ratios being based upon several thousand analyses are of more value than those shown in Table I. The figures for the protein-fat ratio for the different breeds are as follows:

1 This Jovrnal;, 1, 256.

2 J. Am. Chem. Soc., 80, 1166. 


\begin{tabular}{|c|c|c|c|c|c|}
\hline & $\begin{array}{c}\text { Protein-fat } \\
\text { ratio } \\
\text { Van Slyke }\end{array}$ & $\underset{\text { Table I }}{\text { From }}$ & $\mathrm{Br}$ & $\begin{array}{l}\text { Protein-fat } \\
\text { ratio } \\
\text { Van Slyke }\end{array}$ & $\begin{array}{l}\text { From } \\
\text { Table I }\end{array}$ \\
\hline & $1: 0.87$ & $\begin{array}{l}1: 0.86 \\
1: 0.83\end{array}$ & $n$. & $\begin{array}{l}1: 0.80 \\
1: 0 \\
0\end{array}$ & \\
\hline & $1 \because 082$ & $1: 0$ & sey & $1: 0.66$ & $1: 0.71$ \\
\hline
\end{tabular}

There seem to be three groups of cows according to the protein-fat ratio, those of the Jersey type with the protein-fat ratio below 0.7 , those of the Holstein type with the protein-fat ratio above 0.85 , and the balance of the breeds with a protein-fat ratio about 0.8 . Van Slyke has given for the approximate calculation of the proteins from the fat, the formula $\mathrm{P}=0.4(\mathrm{~F}-3)$ +2.8 where $P$ equals proteins and $F$ equals the fat. where $S$ equals the milk sugar, $T S$ the total solids, $F$ the fat, and 0.7 the ash.

It was found that the values of $S$ obtained by both formulas were nearly the same when the milk was pure and varied from 4.5 to 5 per cent. In skimmed or watered samples, the values disagreed and were above 5 in the former and below 4 per cent in the latter. A table was then prepared, using the above formulas for milk with solids from 10.5 to I $_{2.5}$ per cent and fat from 2.5 to 4 per cent. This table has been in constant use for 5 years for the purpose of distinguishing between skimmed milk, whole milk and watered milk. From

Table III-Calculated Sugar

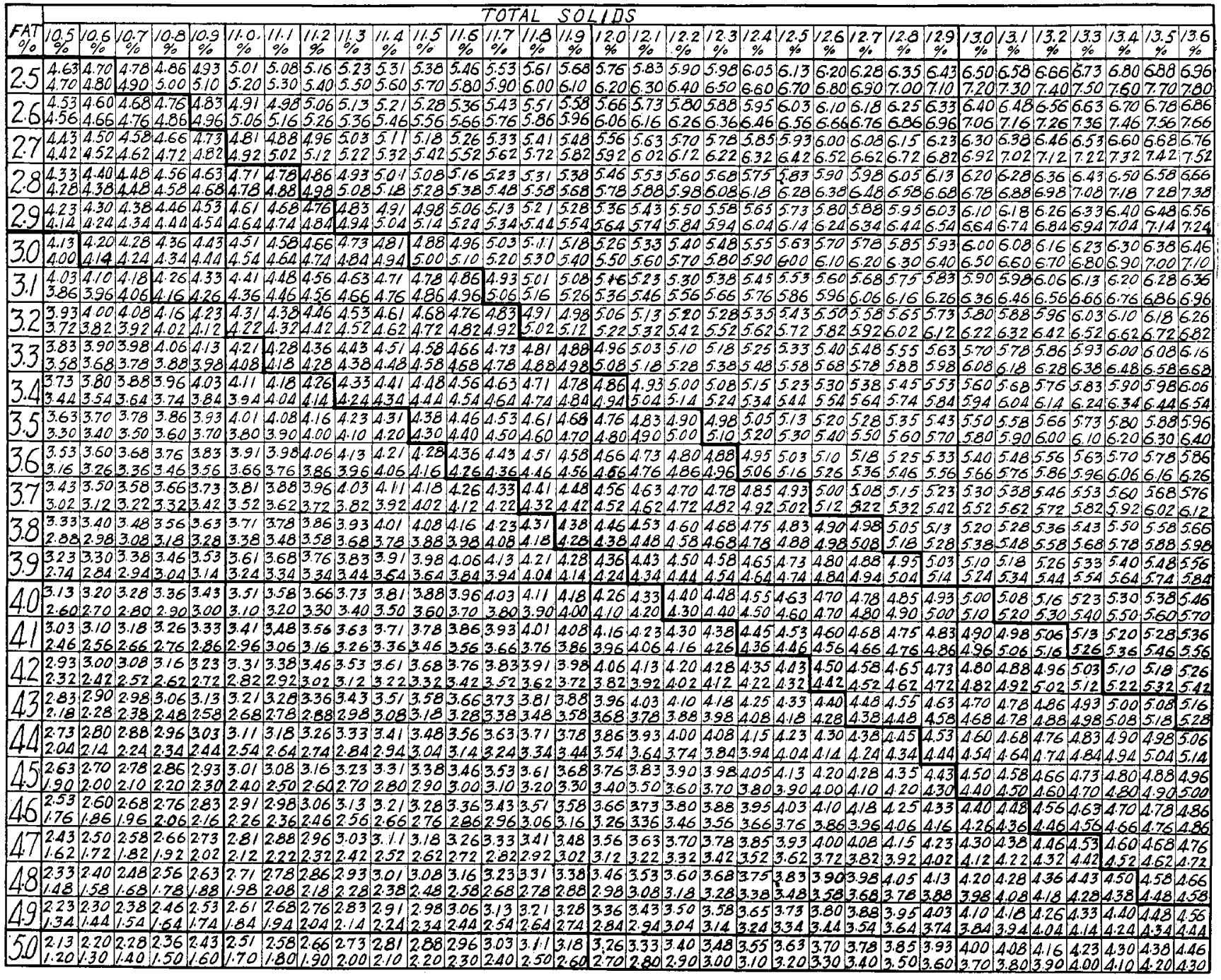

Shortly after the Olson formula was published, it occurred to the writer that since Olson's formula and that of Van Slyke were correct only when applied to pure milk, a combination of both formulas might be used in distinguishing between pure and adulterated milk. The sugar was chosen as the possible index and calculations were made upon many samples of milk, using the following formulas:

$$
\begin{aligned}
& \text { I. } \quad \mathrm{S}=\mathrm{T} \mathrm{S}-[\mathrm{F}+0.7+(\mathrm{T} \mathrm{S}-\mathrm{T} \mathrm{S})] \\
& \text { II. } \mathrm{S}=\mathrm{T} \mathrm{S}-[\mathrm{F}+0.7+(0.4(\mathrm{~F}-3))+2.8]
\end{aligned}
$$

an extension of this table a list of the maximum and minimum fat corresponding to the total solids from I0.5 to 4 per cent was prepared and published in the I 909 report of the Massachusetts State Board of Health. Subsequent experience, however, has shown that for practical purposes, the maximum and minimum values could be placed farther apart. In Table III of calculated sugar, the upper values for the sugar were obtained by Formula I, the lower values by Formula II. The positions of the heavy lines were determined by allowing the variations of not more than 
one-tenth in the calculated sugar values. The samples falling above the other heavy lines may be suspected of being skimmed, those falling below the lower line may be watered, and those falling between these lines are probably normal milk. If a sample is both skimmed and watered, it may be classed in this table as normal milk, but usually, when both such acts are performed, either one or the other preponderates to such an extent that the sample will appear adulterated.

Five hundred and seventy-four samples of milk of known purity and 2 I 68 commercial samples which could not be declared adulterated with a variation in solids from I I to I 3.6 per cent have been tabulated with reference to the relation between the solids and the fat and the results of this tabulation are shown sample is either watered or skimmed as the case may be. Considerable more work must be done, however, involving the tabulation of several thousand analyses of samples of known purity milk from individual cows in order to establish the accuracy of the above statement.

MILK SERUM-Milk serum has been extensively used for the detection of added water in milk ${ }^{2}$ and its value for this purpose is due to the fact that in the preparation of serum the most variable components of the milk, the fat and casein, have been removed. Of the various methods for the preparation of the serum, the writer prefers the copper method on account of the simplicity and rapidity of its preparation, because it can be prepared without heat and requires but a small quantity of milk. With the small beakers now in use with the

TABLE IV

Relation between the Total Solids and Fat of 2168 Samples of Milk Which Were Not Declared Adulterated

\begin{tabular}{|c|c|c|c|c|c|c|c|c|c|c|c|c|c|c|c|c|c|c|c|c|c|c|c|c|c|c|c|c|}
\hline $\begin{array}{c}F A T \\
P E R C E N T\end{array}$ & 11.0 & 11.1 & 11.2 & 11.3 & 11.4 & 11.5 & 11.6 & 11.7 & 11.8 & 11.9 & 12.0 & $\begin{array}{r}7 \\
12.1 \\
\end{array}$ & $\frac{07}{12.2}$ & $\overline{A L}$ & $\begin{array}{l}\mathrm{SOL} \\
2.4 \\
\end{array}$ & $\frac{105}{12.5}$ & $\frac{P E}{\mid 2.6}$ & $\frac{R C}{\mid 12.7}$ & $\begin{array}{l}E N 7 \\
12.8 \\
\end{array}$ & 2.9 & 13.0 & 13.1 & 13.2 & 13.3 & 13,4 & 13.5 & 136 & $\begin{array}{l}\text { NO. OF } \\
\text { SAMPLES }\end{array}$ \\
\hline 2.5 & & & & & & & & & & & & & NUI & $M B E$ & $E R O$ & $J F S$ & $A M P$ & $P / E S$ & & & & & & & & & & \\
\hline 2.6 & & & & & & & & & 1 & & & & & & & & & & & & & & & & & & & $i$ \\
\hline 2.7 & & & & & 1 & 1 & & & & & & & & & & & & & & & & & & & & & & 2 \\
\hline 2.8 & 1 & & 1 & 1 & 1 & 1 & 2 & & & & & & & & & & & & & & & & & & & & & $y$ \\
\hline 2.9 & & 1 & 7 & $i$ & 2 & 2 & & 2 & 3 & 2 & & 1 & & & & & & & & & & & & & & & & 15 \\
\hline 3.0 & 2 & & 3 & 3 & 3 & 3 & $I$ & 3 & 3 & & 2 & 1 & & & & & & & & & & & & & & & & 26 \\
\hline 3.1 & & & 2 & 2 & 4 & 3 & 3 & 2 & 4 & 4 & 4 & 6 & 4 & 4 & & & & & & & & & & & & & & 42 \\
\hline 3.2 & 1 & 1 & & 3 & 1 & 7 & 6 & 8 & $y$ & 5 & 7 & $y /$ & 15 & 3 & 2 & 2 & 2 & 4 & & 1 & & & & & & & & 86 \\
\hline 3.3 & & & 2 & & 2 & 5 & 5 & 16 & 14 & 14 & $\angle Z$ & 6 & 8 & 7 & 6 & 6 & 5 & 4 & & & & & 1 & & & & & 113 \\
\hline 3.4 & & & & 2 & 4 & 1 & 3 & 4 & 5 & 7 & 9 & 14 & 18 & 14 & 13 & 12 & 8 & 6 & 6 & 4 & 1 & & & & & & & 131 \\
\hline 3.5 & & & & & 2 & 4 & 1 & 1 & 6 & 7 & 13 & 13 & 20 & 23 & 21 & 12 & 18 & 6 & 2 & 4 & 3 & 2 & & 1 & & & & 159 \\
\hline 3.6 & & & & 1 & 2 & 3 & & 2 & 3 & 2 & 8 & 15 & 15 & 23 & 40 & 28 & 21 & 13 & 9 & 8 & 5 & 5 & 2 & 3 & & 7 & & 209 \\
\hline 3.7 & & & & & 2 & & & 4 & 1 & 6 & 5 & 8 & 11 & 14 & 30 & 22 & 32 & 35 & 32 & 26 & 10 & 4 & 2 & 2 & & 3 & 1 & 250 \\
\hline 3.8 & & & & & & 7 & & 1 & 1 & 1 & 1 & 3 & 4 & 13 & 19 & 20 & 37 & 29 & 42 & 32 & 32 & 12 & 4 & 5 & 11 & & & 258 \\
\hline 3.9 & & & & & & & & & & & 2 & 2 & 8 & 7 & 13 & 14 & 19 & 25 & 27 & 23 & 27 & 18 & 16 & 10 & 1 & 3 & 2 & 217 \\
\hline 4.0 & & & & & & & & & & & 2 & & 5 & $A$ & 1 & 20 & 25 & 27 & 23 & 19 & 21 & 22 & 20 & 10 & 81 & 5 & 3 & 215 \\
\hline 4.1 & & & & & & & & & & & 1 & & & & 3 & 4 & 3 & 10 & 8 & 17 & 16 & 26 & 12 & 21 & 10 & 8 & 3 & 142 \\
\hline 4.2 & & & & & & & & & & & & & & & 2 & 2 & 3 & 2 & 7 & 3 & 9 & 8 & 16 & 13 & 17 & 12 & 10 & 104 \\
\hline 4.3 & & & & & & & & & & & & & & & 1 & 1 & & 2 & I & 1 & 3 & 8 & 7 & 7 & 7 & 14 & 8 & 60 \\
\hline $4 \cdot 4$ & & & & & & & & & & & & & & & 1 & & & & & 2 & 6 & 1 & 8 & 3 & 15 & 13 & 8 & 57 \\
\hline 4.5 & & & & & & & & & & & & & & & 1 & & & & & & 1 & 1 & 2 & 6 & 5 & 8 & 6 & 30 \\
\hline $4 \cdot 6$ & & & & & & & & & & & & & & & & & & & & & 3 & 3 & 2 & 4 & 6 & & 5 & 23 \\
\hline 4.7 & & & & & & & & & & & & & & & & & & & & & & & 3 & 1 & & 5 & 1 & 10 \\
\hline 4.8 & & & & & & & & & & & & & & & & & & & & & 1 & & & & & 5 & 1 & 7 \\
\hline 4.9 & & & & & & & & & & & & & & & & & & & & & - & 1 & & 1 & & & 1 & 3 \\
\hline & & & & & & & & & & & & & & & & & & & & & & & & & & & & \\
\hline $\begin{array}{l}\text { NO. OF } \\
\text { SAMPLES }\end{array}$ & 5 & 2 & 9 & 13 & 26 & 31 & 21 & 43 & $\triangle B$ & 48 & 66 & 80 & 108 & $1 / 2$ & 153 & 143 & 173 & 163 & 157 & 140 & 138 & $1 / 1$ & 95 & 87 & 70 & 77 & 49 & 2168 \\
\hline
\end{tabular}

in Tables IV and V. In both of these tables the zone of pure milk is indicated as in Table III. It appears from these tables that the methods in use for the detection of added water are efficient but that those for the detection of skimming are not so reliable. A larger percentage of known milk purity fell below the lower heavy line than of the commercial samples not declared adulterated. The samples above the upper heavy line which may be suspected of being skimmed, constituted $I 7$ per cent of the known purity samples and 47 per cent of the commercial samples. Of the samples containing less than 3.3 per cent of fat, 5 per cent of the known purity samples and 68 per cent of the commercial samples were above the upper heavy line. Table III is intended solely for the purpose of selecting the particular samples which are to be subjected to other tests for adulteration and to give a positive indication of the character and possible extension of the adulteration. From Table $V$ it would seem that if a sample was 0.4 above or 0.4 below the maximum or minimum fat figure corresponding to the solids the
Zeiss immersion refractometer, it is possible to obtain sufficient filtrate from a $10 \mathrm{cc}$. sample and if one is in a hurry i $7.6 \mathrm{cc}$. of milk will give sufficient filtrate in a few minutes. This method has been criticized by the author ${ }^{2}$ and subsequently by Ackermann ${ }^{3}$ on account of the dilution necessary in the preparation of the serum, but this is offset by less variation in the serum from different samples. It has another disadvantage, that it is not possible to use the values of the ash of the copper serum in detecting added water because the amount of copper in the serum is higher in watered milk than in unwatered milk and consequently the ash in the serum of watered samples is but little less than in the serum of the original milk before watering. This objection is also applicable to the calcium chloride serum of Ackerman, owing to the precipitation of the calcium phosphate in the preparation of the serum. ${ }^{4}$

1 For an extensive and complete review of the literature on this subject, see Arb. Kais. Gesundheits., 40, Heft. 3.

2 Eighth Intern. Congr. of Appl. Chem., 1, p. 308.

3 Z. Nahr. Genussm., 24 (1912), 612

4 Arb. Kais. Gesundheits.; 40, p.p. 248, 255 and 256. 
The acetic method as modified by Pfyl and Turnau is fairly rapid when only a few samples are examined. It can be prepared at the room temperature, the dilution is but 2 per cent and the ash figures increased by $2.2 \mathrm{I}$ per cent are comparable with those obtained hibits signs of becoming sour, the only serum that should be prepared is the spontaneously obtained sour serum.

RELATION BETWEEN THE CONSTituents OF MILK SERUM-Milk serum consists of water, sugar, lactic

TABI $\mathrm{V}$

Relation between the Total Solids and Fat of 574 Samples of Milk of Known Purity

\begin{tabular}{|c|c|c|c|c|c|c|c|c|c|c|c|c|c|c|c|c|c|c|c|c|c|c|c|c|c|c|c|c|}
\hline \multirow{2}{*}{$\begin{array}{c}\text { FAT } \\
\text { PER CENT }\end{array}$} & \multicolumn{27}{|c|}{ TOTAL SOLIOS PER CENT } & \multirow{2}{*}{$\begin{array}{l}\text { NO. OF } \\
\text { SAMPLES }\end{array}$} \\
\hline & 11.0 & 11.1 & 11.2 & $1 / \cdot 3$ & 11.4 & 11.5 & 11.6 & 11.7 & 11.8 & 11.9 & 12.0 & 12.1 & 12.2 & 12.3 & 12.4 & $1 / 2.5$ & 12.6 & $1 / 2.7$ & 12.8 & 129 & 13.0 & 13.1 & 13.2 & 133 & 13.4 & 13.5 & 136 & \\
\hline 2.5 & & & & & & & & & & & & & \multicolumn{6}{|c|}{ NUMBER OF SAMPLES } & & & & & & & & & & \\
\hline 2.6 & & & & & & & & & & & & & & & & & & & & & & & & & & & & \\
\hline 2.7 & & & & & & & & & & & & & & & & & & & & & & & & & & & & \\
\hline 2.8 & 7 & 7 & & 1 & & & & & & & & & & & & & & & & & & & & & & & & 3 \\
\hline 2.9 & 1 & & 1 & 2 & & & 7 & & & & & & & & & & & & & & & & & & & & & 5 \\
\hline 3.0 & 2 & 1 & 2 & 2 & 3 & 7 & & 1 & 1 & & & & & & & & & & & & & & & & & & & 13 \\
\hline 3.1 & 2 & & 1 & 2 & 2 & 7 & & 2 & 2 & & 7 & & & & & & & & & & & & & & & & & 13 \\
\hline 3.2 & 2 & 1 & 6 & 2 & 2 & 7 & 2 & 4 & 4 & & 3 & & 1 & & & & & & & & & & & & & & & 28 \\
\hline 3.3 & 1 & 2 & 2 & 5 & 4 & 3 & 6 & 3 & 5 & 2 & 4 & 2 & 2 & 2 & & & & & & & & & & & & & & 43 \\
\hline 3.4 & & & 2 & 2 & 4 & 4 & 3 & 6 & 3 & 4 & 31 & 4 & 2 & 1 & & & 1 & & & & & & & & & & & 41 \\
\hline 3.5 & & & & 2 & 7 & 2 & 3 & 2 & 4 & 3 & 6 & 7 & 7 & 1 & 5 & 3 & 2 & 7 & & & & & & & & & & 49 \\
\hline 3.6 & & & 1 & 1 & & & 2 & 2 & 3 & 2 & 7 & 5 & 6 & 5 & 4 & 4 & & 1 & & & & & & & & & & 43 \\
\hline 3.7 & & & 1 & & & 1 & & 3 & 3 & 1 & 4 & 4 & 3 & 6 & 4 & 6 & 5 & 3 & 2 & 1 & & & & & & & & 47 \\
\hline 3.8 & & & & & & & & & 21 & & 2 & 3 & 6 & 4 & 3 & 5 & 3 & 2 & 2 & 2 & & & & & & & & 34 \\
\hline 3.9 & & & & & & & & & & & & 2 & 3 & 2 & 1 & 3 & 7 & 2 & 8 & 4 & 5. & 1 & 2 & & & & & 40 \\
\hline 4.0 & & & & & & & & & & & 1 & 7 & 1 & 3 & 1 & 3 & 4 & 2 & 9 & 7 & 3 & 3 & 2 & 2 & 2 & & & 44 \\
\hline 4.1 & & & & & & & & & & & & & 1 & & 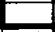 & 2 & 2 & 2 & 3 & 3 & 7 & 5 & 3 & 7 & 1 & & & 30 \\
\hline 42 & & & & & & & & & & & & & & & 1 & 1 & 2 & 2 & 5 & & 2 & 5 & 5 & 6 & 4 & & & 33 \\
\hline $4 \cdot 3$ & & & & & & & & & & & & & & & 2 & 3 &. & 1 & 2 & 1 & 1 & 3 & 2 & 6 & 4 & 6 & 2 & 33 \\
\hline 4.4 & & & & & & & & & & & & & & & & & 1 & 2 & 1 & 2 & 2 & 1 & 4 & 3 & 4 & 2 & 2 & 24 \\
\hline 4.5 & & & & & & & & & & & & & & & & & 1 & 2 & & 2 & 1 & 3 & 7 & 2 & 3 & 3 & 4 & 22 \\
\hline 4.6 & & & & & & & & & & & & & & & & & & & & & 1 & 7 & 4 & 2 & & 1 & 3 & 12 \\
\hline 4.7 & & & & & & & & & & & & & & & & & & & & & & 1 & 1 & 2 & 2 & 2 & 3 & 11 \\
\hline 4.8 & & & & & & & & & & & & & & & & & & & & & & & 1 & 1 & 2 & 1 & & 5 \\
\hline 49 & & & & & & & & & & & & & & & & & & & & & & & & & & 1 & & 1 \\
\hline & & & & & & & & & & & & & & & & & & & & & & & & & & & & \\
\hline $\begin{array}{l}\text { NO. OF } \\
\text { SAMPLES }\end{array}$ & 9 & 5 & 16 & 19 & 16 & 13 & 17 & 23 & 27 & 12 & 33 & 28 & 32 & 24 & 21 & 30 & 28 & 20 & 32 & 22 & 22 & 23 & 25 & 25 & 22 & 16 & 14 & 574 \\
\hline
\end{tabular}

from the sour serum. The greatest value of the sour serum is in the preparation of the ash. Using $25 \mathrm{cc}$. of sour milk serum there is less than $2 \mathrm{~g}$. of organic matter to be burned and the influence of the combustion of this upon the I90 milligrams of ash is slight. It is advisable to apply this test in addition to the refraction or specific gravity of the serum to all samples suspected of containing added water, for both figures depend upon different milk constituents and, furthermore, if milk is declared adulterated by both methods, it eliminates the possibility of the samples being naturally abnormal milk obtained from a sick cow. It will be noticed in Table I that the refraction of the sour serum is midway between that of the copper serum and the acetic serum. This should be borne in mind when making examinations of milk which have par- acid, more or less protein, and mineral matter, depending upon the mode of preparation. The acetic serum contains sugar, coagulable albumen, protein precipitated by tannic acid and all the mineral matter. The sour serum contains the same substances in addition to lactic acid formed from the sugar. The copper serum contains the sugar, coagulable albumen, protein precipitated by tannic acid, and some of the mineral matter. The calcium chloride serum contains the sugar, proteins precipitated by tannic acid, and a portion of the mineral matter, but no coagulable albumin.

The refractive index of milk serum is an additive property consisting of the sum of the refractive indices of its constituents, and except in the case of the calcium chloride serum, bears no absolute relation to the com-

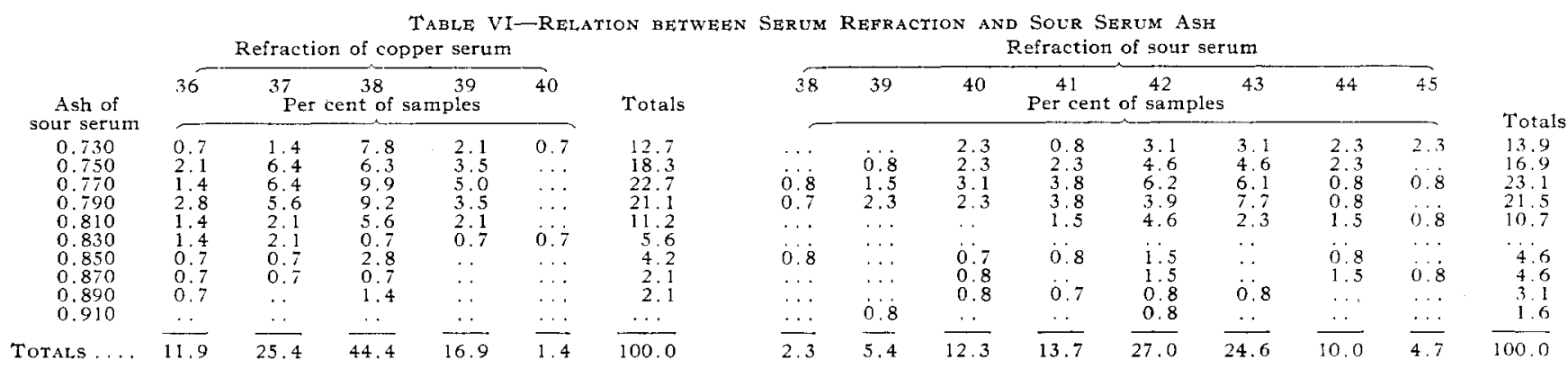

tially soured. Under such circumstances, the copper serum so prepared will give a higher reading and the acetic serum a lower reading than would be given by the same sample before souring. When a sample ex- position of the milk from which it was made. In the calcium chloride serum, the refractive indices follow very closely the percentage of sugar in the milk. There is no specific relation between the ash of the 
sour serum and the other properties of the serum of pure milk, as shown in Table VI, computed from the refractions of copper serums of I42 samples, the refraction of the sour serum of 130 samples, and the ash of the sour serums of the same samples.

It is possible, however, if one knows the refractive indices of the milk serum to calculate with accuracy the specific gravity or the solids of the same serum. The Lorenz and Lorentz formula $\frac{n^{2}-I}{n^{2}+2} \cdot \frac{I}{d}=K$ where no difference in the value of $K$, provided that the refractive index and specific gravity are determined at the same temperature and the latter referred to water at $4^{\circ} \mathrm{C}$. Where the values of $n$ and $d$ are obtained at different temperatures, the value of $K$ varies with the temporature. In the formula ${ }_{c}^{n-} n^{1}=A, n$ and $n^{1}$ must be determined at the same temperature. The value of $K$ in the copper serum is slightly less in watered milk than in whole milk, due to the fact that while
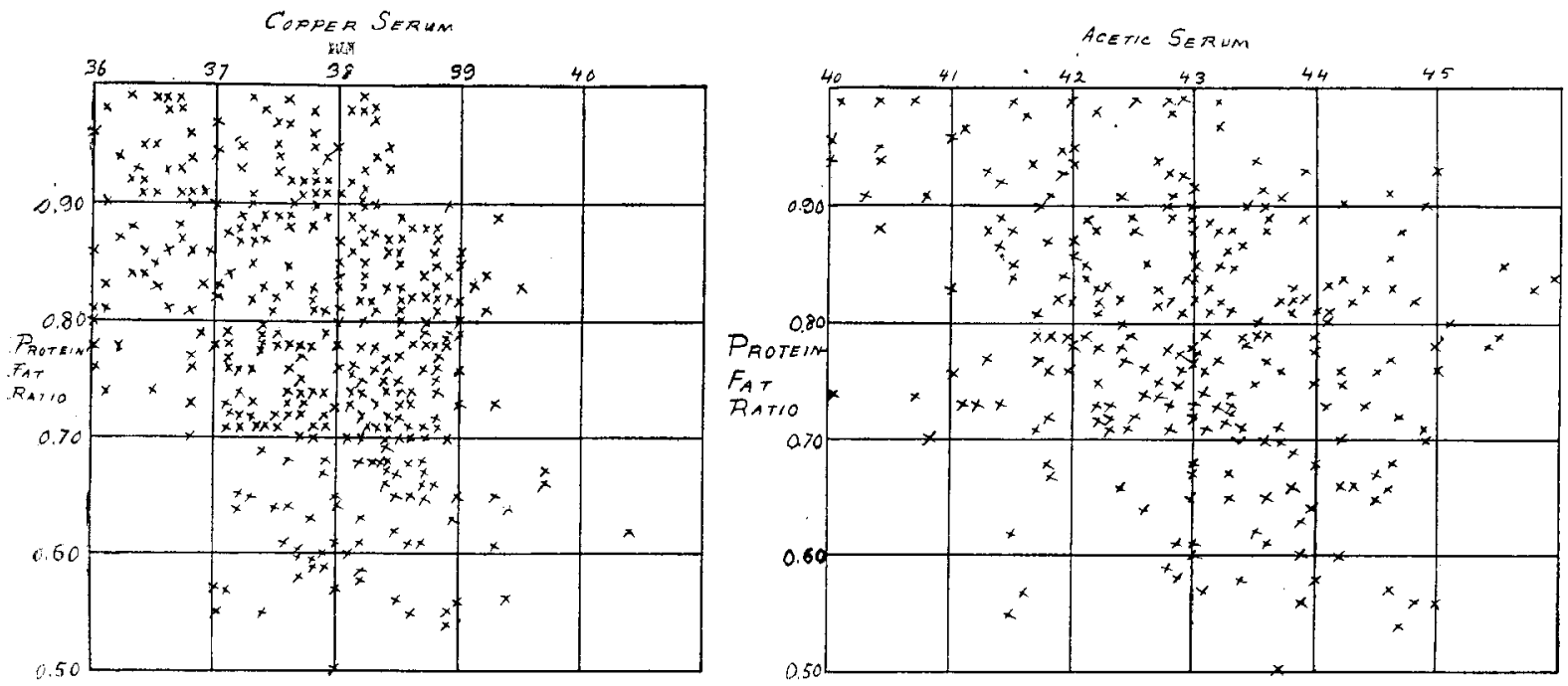

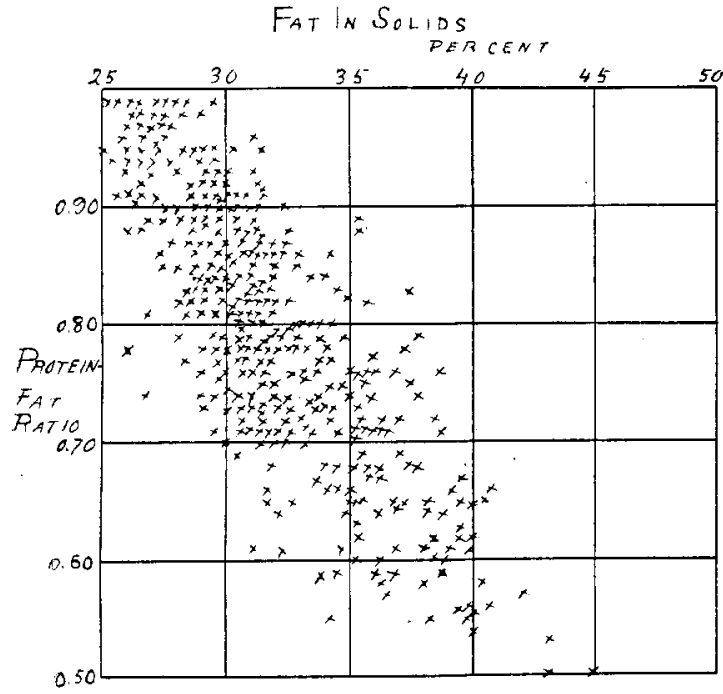

$n$ equals the refractive index, $d$ the specific gravity, and $K$ a constant, is uniform for various concentrations of milk serum and may be used to calculate the specific gravity from the refractive index. The formula evolved by Walter and Robertson ${ }^{1} \frac{n-n^{1}}{c}=A$ where $n$ equals the refractive index of the solution, $n^{1}$ the refractive index of the solvent, $c$ the concentration of the solution, and $A$ a constant, is applicable for the calculation of solids of the milk serum. The values of these constants are given below. In the Lorenz and Lorentz formula, the difference in temperature makes

1 Wied Ann., 38 (1889), 107; J. Phys. Chem., 13 (1909), 469.

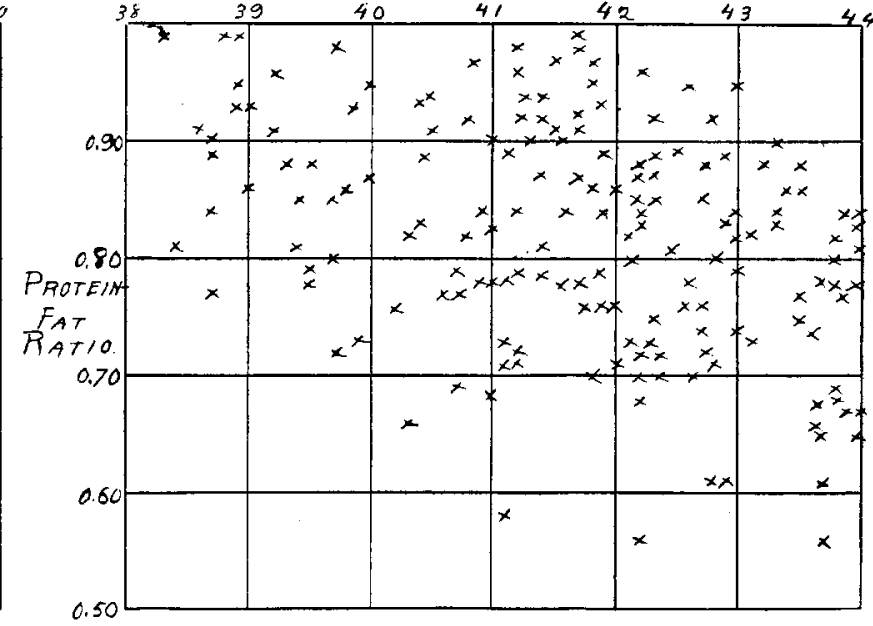

the refraction of the copper solution is about the same as that of the milk serum, its specific gravity is higher. The variation, however, is too slight to have any marked effect upon the calculation of the specific gravity from the refractions. Table VIII gives the value of the specific gravity and solids calculated from the refraction figures of the acetic and copper serums and of the specific gravity calculated from the sour serum.

RELATION OF THE PROTEIN-FAT RATIO TO SERUM REFRACTION--It will be seen from Table $I$ that in the samples obtained from Jersey and Guernsey cows, no figures for copper refraction were obtained below 37.0 and the figures for the protein-fat ratio were all less 


\begin{tabular}{|c|c|c|c|}
\hline TABLE & VII-RELATION & BETWEEN SERUM & ONSTANTS \\
\hline & $n^{2}=1 \cdot d=K$ & $\cdot$ & $n-n^{1}=A$ \\
\hline Calcium chloride & $\begin{array}{l}n^{2}+2 \cdot 1 \\
n \text { at } 17.6^{\circ} \mathrm{C} \\
d \text { at } 15 / 15^{\circ} \mathrm{C} \\
n \text { at } \mathrm{X} . \\
\end{array}$ & $K=0.2056(a)$ & $\bar{c}=A$ \\
\hline Acetic & $\begin{array}{l}d \text { at } \mathrm{X}^{\circ} 4^{\circ} \mathrm{C} \text {. } \\
n \text { at } 20^{\circ} \mathrm{C} \cdot 5^{\circ} \mathrm{C} \text { at } 15^{\circ} 15^{\circ} \mathrm{C} \text { at } \mathrm{X}^{\circ} \mathrm{C} \cdot \mathrm{C}\end{array}$ & $\begin{array}{l}K=0.2058(a) \\
K=0.20554(b)\end{array}$ & $A=0.00158(b)$ \\
\hline Copper & $\begin{array}{l}d \text { at } \\
n \text { at } 20^{\circ} \mathrm{C} . \\
d \text { at } 15^{\circ} 15^{\circ} \mathrm{C} \text {. } \\
n \text { at } \mathrm{X}\end{array}$ & $\begin{array}{l}K=0.20592(b) \\
K=0.20484\end{array}$ & $A=0.00158(b)$ \\
\hline Sour & 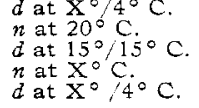 & $\begin{array}{l}K=0.20526(b) \\
K=0.20581 \\
K=0.20607(b)\end{array}$ & \\
\hline
\end{tabular}

(b) Weigner and Yakuwa, Milchwertsch. Zentr., 5 (1909), 473.

than 0.82 and from the average figures it appears that as the protein-fat ratio increases, the concentration of the serum diminishes. All the refraction figures corresponding to protein-fat ratio above 0.50 have been TABLE VIII-COMPARISON BETWEEN REFRACTIVE INDICES AND OTHER
CONSTANTS OF MILK SERUM (CALCULATED FROM FORMULAS GIVEN IN TABLE VII)

\begin{tabular}{|c|c|c|c|c|c|c|c|c|c|}
\hline \multirow{2}{*}{$\begin{array}{l}\text { Scale } \\
\text { reading } \\
20^{\circ} \mathrm{C} \text {. }\end{array}$} & \multirow[b]{2}{*}{$\begin{array}{c}n \mathrm{D} \\
20^{\circ} \mathrm{C} .\end{array}$} & \multicolumn{3}{|c|}{$\begin{array}{l}\text { ACETIC SERUM } \\
\text { olids Sp. gr. }\end{array}$} & \multicolumn{3}{|c|}{$\begin{array}{l}\text { COPPER SERUM } \\
\text { olids Sp. gr. }\end{array}$} & \multicolumn{2}{|c|}{$\begin{array}{l}\text { SoUR SERUM } \\
\text { Sp. gr. }\end{array}$} \\
\hline & & cent 1 & $/ 15$ & $14^{\circ}$ & cent & $/ 15$ & $20^{\circ} / 4^{\circ}$ & $15 \% 15$ & $20^{\circ} / 4^{\circ}$ \\
\hline & $\begin{array}{l}1.3 \\
1.3 \\
1.3 \\
1.3 \\
1.3 \\
1.3 \\
1.3 \\
1.3 \\
1.3 \\
1.3 \\
1.3 \\
1.3\end{array}$ & 3.30 & $\begin{array}{l}1.0211 \\
1.0221 \\
1.0231 \\
1.0242 \\
1.0252 \\
1.0262 \\
1.0273 \\
1.0283 \\
1.0293 \\
1.0303 \\
1.0313 \\
1.0323\end{array}$ & & $\begin{array}{l}5 \\
6 .\end{array}$ & 1.0184 & $\begin{array}{l}4 \\
4 \\
4 \\
4\end{array}$ & & \\
\hline
\end{tabular}

plotted and the results are shown in the chart on page go6. From this chart, it is apparent that normal milk with a protein-fat ratio less than 0.70 , should give sera with refractive indices above 37 by the copper serum, 40 by the sour method, and $4 \mathrm{I}$ by the acetic method. The relation between the protein-fat ratio and the percentage of fat in the solids is shown in the plot. The protein-fat ratio increases as the percentage of fat in the solids decreases; therefore, if the per cent of fat in the solids is high (above 35 ), the sample should give a serum with a high refraction. The consideration

Table IX-Analyses of Herd Milk of Known Purity

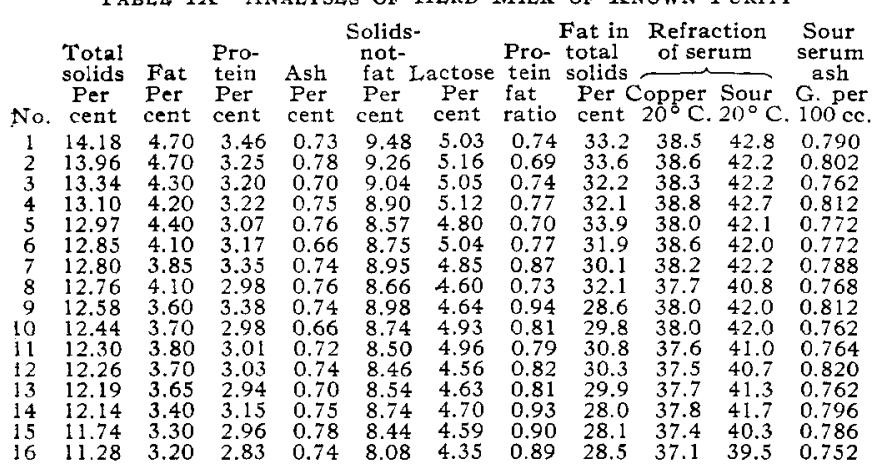

of these relations should be studied in connection with the other figures obtained from the same sample, particularly with the sour serum ash, before the sample is called watered.

During the months of March, April and May of this year, the milk of a large number of herds has been examined in connection with another investigation. From these, sixteen have been chosen, including the samples from which the highest and lowest figures have been obtained; the analyses are recorded in Table IX. The character of the herds, the number of cows and the amount of milk obtained at the milking, is given in Table $X$. None of these analyses were used in the preparation of Table $\mathrm{I}$.

Sample No. I 2 was obtained from a celebrated.herd of thoroughbred Holstein Fresian cows, the majority of which were in the last stages of lactation. Sample

$$
\begin{aligned}
& \text { Table } \mathrm{X} \text {-Character of Herds Propucing the Milk Recorded in } \\
& \text { Grade } \\
& \text { Grade Ayr- } \\
& \begin{array}{l}
\text { Jersey shire } \\
\text { and and Grade Total Wt. of milk }
\end{array}
\end{aligned}
$$

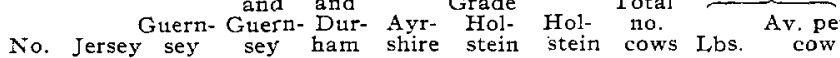

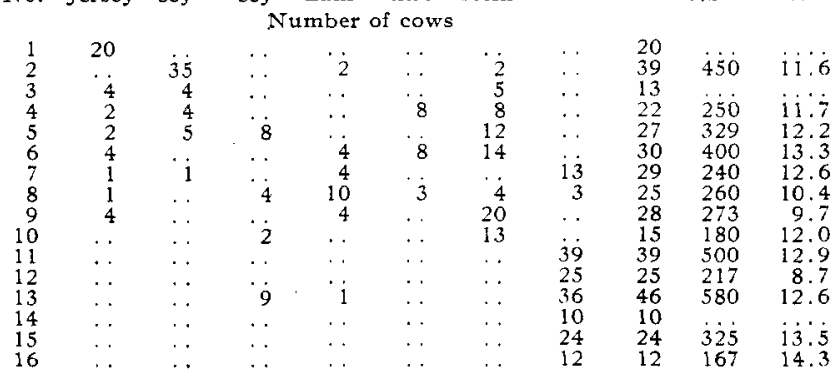

No. $I_{5}$ was obtained from the same herd two months later, many of the cows having freshened since the previous sample was taken. The analyses of these two samples show that while the solids and the fat were both much lower in the second sample taken, there was practically no difference between the figures obtained from the milk serum.

All the other samples were taken from different herds. The milks from herds Nos. I 4, I 5 and $I 6$ are not sold at retail until after being mixed with milk of good quality, in order to bring it up to the requirements of the Massachusetts law.

\section{SUMMARY}

Variations in the composition of milk are due primarily to the breed, and to a less extent to the season of the year and to the time since calving.

The least variable milk constituents are the lactose and ash, both of which are of value in detecting added water.

It is possible, within reasonable limits, to indicate from the percentage of solids and fat, whether or not a sample has been watered, skimmed, or is normal milk.

No relation exists between the refraction of the serum and the sour serum ash; therefore, if both figures are below the minimum for pure milk it is positive indication of the presence of added water.

The protein fat ratios in all cases have been less than I. If this figure exceeds I, skimming is indicated, the amount being greatest in samples possessing the highest ratio.

If the protein-fat ratio is less than 0.7 or the percentage of fat in the solids is above 35.0 , samples may be declared watered by a low refraction of the serum, not 
necessarily below the minimum for all samples of known purity. This is particularly so when dealing with herd milk.

In the absence of a refractometer, the specific gravity or the per cent of solids of the serum is just as valuable as the refractive index in detecting added water.

The writer wishes to acknowledge his thanks to his assistants, Messrs. Charles H. Hickey, Louis I. Nurenberg, and Clarence E. Marsh, to whom he is greatly indebted for their valuable cooperation in making the analyses of the samples.

LABORATORY OF FoOd and DRUG INSPECTION

MassachusetTs State BoARd of Health

$$
\text { Boston }
$$

\section{SOME CHARACTERISTICS OF CHLORINE-BLEACHED FLOUR}

By C. A. A. UTr

Received July 3, 1914

Since the Government ruled against flour treated with the oxides of nitrogen (F. I. D. I00; N. T. 722, U. S. Dept. of Agr.), chlorine-bleached flour has made its appearance. United States Patent I,O7I,977, September 29, I9I3, deals with a process in which "flour is treated with anhydrous chlorine (diluted with an inactive gas) in order to mature and whiten it." This process and a few others in which chlorine is the active agent are used. By this means, it is claimed, the flour is whitened and aged.

That chlorine will bleach flour has been known for many years, but its activity and difficulty of control have caused its use to be viewed with suspicion. In connection with the pure food work of Kansas it was found necessary to collect some information on chlorine-treated flour. The results of this investigation are presented in this paper.

Samples were obtained directly from the mills by the Kansas food inspectors, of the same flour before and after bleaching. These were placed in screwtop glass jars, sealed and shipped to the laboratory. The following determinations were made: (I) Chlorine qualitatively and quantitatively; (2) moisture; (3) acidity. A number of gluten and baking tests were also made.

Chlorine was determined by Jacobs' method as used in the Plant Chemistry Laboratory of the U. S. Department of Agriculture. It is as follows: "To 25 grams of flour in a platinum dish, add $25 \mathrm{cc}$. of a solution containing 25 grams of $\mathrm{KOH}$ and 25 grams $\mathrm{KNO}_{3}$ per liter. Evaporate to dryness on a steam bath, and ignite in a muffle at a dull red heat until thoroughly charred. Extract the charred mass with 25 cc. 5 per cent $\mathrm{HNO}_{3}$; filter. Return residue to the platinum dish, char further and extract again with 25 cc. 5 per cent $\mathrm{HNO}_{3}$; filter, wash with hot water, and ignite to an ash. Dissolve the ash in 5 per cent $\mathrm{HNO}_{3}$, filter and wash. Combine the filtrates and determine the chlorine with silver nitrate."

Qualitative determinations of chlorine. were made by the copper wire method as given by Alway (Bull. I02, Nebraska Experiment Station, page 53) as follows: "One ounce ( $3 \circ$ grams) of flour is extracted with benzene (ether was used) and the latter evaporated. . A small a mount of oil remains. A piece of copper wire is heated in a colorless gas flame until it is black and no longer colors the flame green. The hot end of the wire is dipped into the oil and again brought into the flame. If chlorine or bromine has been used as a bleaching agent a green or blue coloration is produced."

Moisture determinations were made by drying the samples for five hours in a steam oven at the temperature of boiling water.

The determinations of acidity were made in accordance with Method 5 in Bull. I52, of the Bureau of Chemistry, U. S. Department of Agriculture, which is as follows: To $20 \mathrm{grams}$ of flour in a $500 \mathrm{cc}$. Erlenmeyer flask add $200 \mathrm{cc}$. freshly boiled water. Digest. at $40^{\circ} \mathrm{C}$. for two hours, shaking at Io-minute intervals. Decant the clear liquid through a folded filter and titrate $50 \mathrm{cc} . \mathrm{N} / 20 \mathrm{NaOH}$.

Table I indicates the results obtained on inspection samples. It will be noted that the moisture does not vary any more between the bleached and unbleached flour than might be expected in duplicate determinations. An increase in acidity in the bleached

Table I-Some Characteristics of Chlorine-hleached Flour

\begin{tabular}{|c|c|c|c|c|c|c|c|c|c|}
\hline & & \multirow[b]{2}{*}{ 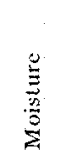 } & \multirow{2}{*}{ 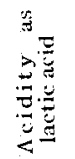 } & \multirow{2}{*}{$\begin{array}{l}\dot{E} \\
\dot{\Delta} \\
\dot{\Delta} \\
\dot{U}\end{array}$} & \multirow{2}{*}{ 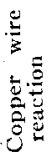 } & \multirow{2}{*}{$\begin{array}{c}\bar{z} \\
\bar{g} \\
\bar{o} \\
\bar{j}\end{array}$} & \multicolumn{2}{|c|}{ Gluten } & $\overbrace{}^{\begin{array}{l}\text { Grade } \\
\text { of loaf }\end{array}}$ \\
\hline No. & & & & & & & $\frac{\vec{\omega}}{3}$ & $\overrightarrow{\hat{\theta}}$ & 总 \\
\hline $46-47$ & Unbleached patent & 13.36 & 0.126 & 484 & - & 1870 & 43.1 & 12.99 & 9495 \\
\hline $48-45$ & $\begin{array}{l}\text { Bleached patent } \text { Unbleached, clear } \\
\text { Uni }\end{array}$ & $\begin{array}{l}13 . \\
14 .\end{array}$ & $\begin{array}{l}0.144 \\
0.198\end{array}$ & $\begin{array}{l}764 \\
532\end{array}$ & \pm & $\begin{array}{l}1800 \\
17.80\end{array}$ & $\begin{array}{l}42.8 \\
47.5\end{array}$ & $\begin{array}{l}13.07 \\
16.10\end{array}$ & $\begin{array}{l}9394 \\
\ldots 83\end{array}$ \\
\hline $52-54$ & $\begin{array}{l}\text { Bleached, clear } \\
\text { Patent unbleached }\end{array}$ & $\begin{array}{l}.14 .18 \\
10.70\end{array}$ & $\begin{array}{l}0.288 \\
0.162\end{array}$ & $\begin{array}{l}916 \\
442\end{array}$ & \pm & $\begin{array}{l}1800 \\
1940\end{array}$ & $\begin{array}{l}48.6 \\
38.87\end{array}$ & $\begin{array}{l}16.07 \\
12.67\end{array}$ & $\begin{array}{ll}\dot{9} & 85 \\
92\end{array}$ \\
\hline & Patent bleached. & .1 .12 & 0.18 & $881^{\circ}$ & + & 1950 & $39: 16$ & 12.87 & 93.89 \\
\hline $65-66$ & Unbleached patent & 12.66 & 0.126 & 556 & - & 2020 & 39.34 & 12.40 & 9492 \\
\hline $95-96$ & Bleached pa & $\begin{array}{l}12.88 \\
12.20\end{array}$ & $\begin{array}{l}0.126 \\
0.144\end{array}$ & $\begin{array}{l}648 \\
494\end{array}$ & \pm & $\begin{array}{l}1980 \\
1920\end{array}$ & $\begin{array}{l}39.98 \\
41.83\end{array}$ & $\begin{array}{l}12.92 \\
14.05\end{array}$ & $\begin{array}{l}9389 \\
94 \quad 94\end{array}$ \\
\hline & Bleached & & 0.189 & 716 & + & 1970 & 41.78 & 13.67 & 9394 \\
\hline $91-92$ & Patent unbleached & 13.10 & 0.126 & $\begin{array}{l}540 \\
844\end{array}$ & $\bar{t}$ & & & & \\
\hline $51-55$ & $\begin{array}{l}\text { Unbleached, clear } \\
\text { Unter beachea }\end{array}$ & 12 & 0.216 & 504 & & & & & \\
\hline & Bleached, clear & 1 & 0.252 & 928 & + & & & & \\
\hline $97-98$ & $\begin{array}{l}\text { Unbleached } \\
\text { Bleached }\end{array}$ & & $\begin{array}{l}0.189 \\
0.198\end{array}$ & $\begin{array}{l}544 \\
868\end{array}$ & $\frac{1}{-}$ & & & & \\
\hline 70299 & Bleached & & 0.198 & 736 & + & & & & \\
\hline $65-63$ & $\begin{array}{l}\text { Bleached } \\
\text { Unbleached }\end{array}$ & 11. & 0.2 & $\begin{array}{l}900 \\
576\end{array}$ & \pm & & & & \\
\hline & Blea & & 0.324 & 667 & - & & & & \\
\hline $70-72$ & Unbleached & & U. & 501 & & & & & \\
\hline $73-71$ & $\begin{array}{l}\text { Bleached } \\
\text { Unbleached }\end{array}$ & & 0.216 & & & & & & \\
\hline & & & & 85 & & & & & \\
\hline
\end{tabular}

flour as compared with the corresponding unbleached sample is noted in nearly every instance. The chlorine content varies from 442 parts per million to 576 parts. per million in the unbleached flour; when bleached the variation is 648 to 972 parts per million. All bleached samples reacted positively with the copper wire reaction for chlorine.

The differences in loaf volume are not much greater than one would expect to find in individual loaves. from the same flour. Loaf volume favors the unbleached flour in some cases, in others the bleached flour. All loaves were graded against a standard loaf made from hard wheat flour under the same conditions, as is the custom. It will be noted that in nearly every case the bread made from the unbleached four grades better. The bleached flour gives a loaf having an objectionable color and texture.

The gluten tests run practically uniform for the bleached and unbleached flour, there being no more difference than on duplicates. However, physically 